Elsevier Science Publishers B.V., Amsterdam - Printed in The Netherlands

\title{
REVIEW OF FIELD OBSERVATIONS OF RUNOFF GENERATION IN THE TROPICS
}

\section{P.L. DUBREUIL}

Office de la Recherche Scientifique et Technique Outre-mer, 70-74 Route d'Aulnay, 93140 Bondy (France).

(Received March 25, 1985; accepted for publication April 19, 1985)

\section{ABSTRACT}

Dubreuil, P.L., 1985. Review of field observations of runoff generation in the tropics. J. Hydrol., 80: 237-264.

Over the last thirty years, French hydrologists have observed flow characteristics at the outlets of small tropical watersheds, characteristics which vary between arid zones, humid zones and equatorial rainforest zones. The main physical phenomena related to the various types of runoff generation have been observed and analysed. The generation of runoff and subsurface runoff following tropical rainstorms depends on soil surface formations, texture and structure as well as vegetation cover, geological substrata; weathered material and climate.

Analysis is also made of experimental rainfall-runoff relationships, the shape of flood hydrographs and the conditions necessary for the occurrence of steady base flow. Scale effects between experimental plot and watershed have been studied to identify any effect this may have upon runoff generation and flow. Tables detail watershed characteristics and relationships between these and rainfall and runoff.

\section{INTRODUCTION}

In the last ten years, computer-based techniques have enabled hydrologists and mathematicians to reconstruct hydrological events using models; in addition to empirical relationships, these models make use of theoretical equations or of equations inferred from laboratory tests conducted on small homogeneous media.

Recent literature reviews the many difficulties raised when such models are extrapolated to other basins. Although recognised, the complexity of the various types of runoff and their conditions of occurrence are not fully understood nor controlled. Modellers and field hydrologists frequently work along slightly different lines, as shown by Dunne (1983), who surveyed field work and theoretical work carried out by researchers mainly from the USA, Australia and the United Kingdom.

Runoff generation occurs at or near the point where rain falls; so small watersheds are often used in analysis and modelling. Nevertheless, a change

$0022-1694 / 85 / \$ 03.30$

$81224 / 2 ; 3$ JU10 1994
๑ 1985 Elsevier Science Publishers B.V.

0.R.S.T.0.M. Fonds Documentaire

$N^{\circ}: 39673$

Cote: 
of scale to large watersheds causes difficulties. Pilgrim et al. (1982) related hydrological characteristics to the size of watershed and environmental parameters, within a geographical region.

This paper reviews the main field observations made by ORSTOM soil scientists and hydrologists working in the tropics over the past thirty years; special emphasis is given to the various process of runoff generation. In the first section, the changing activities of our research groups over this period are described, demonstrating their reasoning and indicating some matters of minor interest. The second section details the main characteristics of runoff processes in tropical zones. Finally, the circumstances under which runoff is generated are described. The relations between hydrology, environment and the size of watersheds will be tackled in a subsequent paper.

\section{HYDROLOGICAL RESEARCH IN THE TROPICS}

Little was known about the hydrometeorology of western tropical Africa in the early $1940 \mathrm{~s}$. Permanent observation networks were inadequate to meet the requirements of the countless public works underway: For example, to help in calculating the size of culverts or bridges for roads and railways and spillways for storage dams. Consequently, several studies were conducted on small watersheds, "representative basins", with areas ranging from 1 to $200 \mathrm{~km}^{2}$; the purpose of the work was to calculate the ten-year flood, using the size and slope of a catchment and the total permeability of its soils as the main parameters. Observations made on 60 basins over a period of one to three years allowed Rodier and Auvray (1965) to publish evaluation standards which are still relevant.

Some gaps in geographical and spatial knowledge still existed so additional watersheds representative of environments not previously investigated were set up, and studies were extended to watersheds smaller than $1 \mathrm{~km}^{2}$ and larger than $200 \mathrm{~km}^{2}$. A considerable amount of information was collected Dubreuil (1972) compiled data from some 250 representative basins for easy reference.

It was at this time that the drought started in the Sahel, soon to become the longest and most severe of the century. The volume of runoff at the outlet of small areas within these semi-arid zones (annual rainfall less than $\mathbf{7 5 0}$ $\mathrm{mm}$ ) then became an important object of research. Although the representative basins were not intended for this purpose, results obtained from them, together with observations from meteorological networks, allowed Rodier (1975) to evaluate annual.runoff in the tropical Sahel.

Over the last twenty years three concepts have helped with the development of hydrological theory for the tropical zones: Unit hydrograph, antecedent precipitation index, and infiltration index. However, some difficulties and incompatibilities are apparent, particularly in the case of tropical rainforests. Several hydrologists point to the existence in temperate wet and cold 
wet zones of subsurface runoff, that often exceeds direct surface runoff. In the tropics, Tixier (1953) reports on subsurface runoff in a tree-savanna watershed close to Bangui in the Central African Republic (1600 mm annual rainfall, thick weathered mantle over quartzites). Other observations have been made for representative basins throughout the rainy season, and are discussed in the second section of the present paper. Only over the past ten years has it been possible to study the physical processes of runoff and their. variation in space and time.

A study area more homogeneous than the $10 \mathrm{~km}^{2}$ representative basin was needed and basins of a few hectares and plots of a few $\mathrm{m}^{2}$. were set up. Detailed soil maps were drawn and soil-water dynamics analysed in order to better understand the observed phenomena. In order to limit variable factors, tests were made with simulated rainfall. Lafforgue (1977) analysed the elementary processes of runoff and infiltration on plots in western Africa and confirmed several results obtained from watersheds, such as the existence of an initial rainfall before ponding, limiting runoff intensity and type of rainfall-runoff relationship. This work demonstrated the continuity of the major physical processes between a scale of about $10 \mathrm{~m}^{2}$ and several $\mathrm{km}^{2}$, even when the intensity of behaviour is very variable.

In a semi-arid zone, a global conceptual model based on the hypothesis of a flow due mainly to direct runoff allowed Girard (1975a) to evaluate the interannual variability of flow in some 30 watersheds of $1-150 \mathrm{~km}^{2}$; this provided the additional information necessary for the development of drought-proof reservoirs. A global tank model can be applied to tropical watersheds with higher rainfall, where the more complex runoff includes a subsurface component and aquifer drainage. The spatial heterogeneity of rainfall, soils and vegetation is represented by the set of production functions of the tank model and by a square grid system. In this way Girard (1975b) was able to model flows in a $1000 \mathrm{~km}^{2}$ watershed in the south of Mauritania (mean annual rainfall of $475 \mathrm{~mm}$ ), despite degradation of the drainage network and the consequent effects for flooding. Given the experimental nature of this research, the use of the strict physical laws of infiltration or evapotranspiration as the basic elements of models would have been untimely without the information necessary to obtain an optimum fit.: These simple models were suitable for calculating floods or evaluating annual flows. But we agree with Dunne (1983) that the accurate simulation of any flow with a small time interval requires models that are sophisticated with respect to strict physical assumptions that require field research and measurement.

Despite the priority apparently given to the practical objectives, ORSTOM's research has made possible a detailed understanding of the physical processes of flow. The characteristics of these processes, which are peculiar to the various tropical zones, can now be outlined. 
The characteristics of tropical hydrological regimes have most frequently been classified by climate. Rodier (1964) has drawn up a classification for tropical west Africa. The desert regime (less than $100 \mathrm{~mm}$ mean annual rainfall) is not included here. Three environments are considered: (1) the arid and semi-arid environment, with annual rainfall of $100-750 \mathrm{~mm}$; climax vegetation varying from herbaceous steppe to bush; (2) transitional humid tropical and humid tropical, with annual rainfall above $750 \mathrm{~mm}$ but not exceeding 1600-1700 mm; climax vegetation: Bush to tree savanna; and (3), the wet equatorial climate (two rainy seasons) with annual rainfall above $1200 \mathrm{~mm}$; climax vegetation: Rainforest.

As we are dealing here only with runoff generation, only the major physical characteristics of areas smaller than $200 \mathrm{~km}^{2}$ are used.

(1) The arid and semi-arid environment in western Africa south of the Sahara covers a large stretch from the Senegalese-Mauritanian coasts to the frontier between Chad and the Sudan, lying between the 100 and $750 \mathrm{~mm}$ isohyets, i.e. almost entirely confined by lines of latitude $16^{\circ}-18^{\circ}$ and $12^{\circ}-$ $14^{\circ} \mathrm{N}$. About two thirds (i.e. $600,000 \mathrm{~km}^{2}$ ) of the Drought Polygon of northeast Brazil also falls into this category (between $5^{\circ}$ and $12^{\circ} \mathrm{S}$ ).

Where rainfall is concentrated into a 2-3 month period, direct runoff is the norm, especially where aridity is intense. Two factors affect this runoff: the moisture content of the upper soil layers and the formation of surface states (improperly called "crusts") which are caused by the first rains and which prevent infiltration. Runoff is absent or infrequently observed on permeable soils without a crust.

Initial streams are often formed close to the drainage divides, but there is rapid degradation of the drainage network. The main stream of a watershed covering some tens of $\mathrm{km}^{2}$ almost always shows marked degradation of the channel pattern affecting the high-water channel and flood plain; water losses are considerable. In these areas no base flow occurs between floods, or it lasts a few days or weeks at most. Except where perennial springs drain aquifers in mountains or high plateaux, flow ceases after the rainy season.

(2) The humid tropical environment is $\mid$ represented in western and central Africa by the zone south of the semi-arid stretch and north of the evergreen rainforest associated with the $1600-1800 \mathrm{~mm}$ isohyet. It also covers a large part of Madagascar and the remaining third of the Brazilian Drought Polygon.

Rainfall is distributed over a $4-6$ month period and base flow continues in small streams during the dry season where soil conditions, geology and topography so permit. Runoff remains the main component of flow, depending on the antecedent moisture index of the soil and the influence of the rapid growth of vegetation in the rainy season.

Subsurface runoff occurs in most cases and may be important on some 
soils and topography, for example on the laterite tablelands characterized by deep permeable and often indurated soils with ironstone, rising above narrow valleys where direct and subsurface runoffs are sometimes clearly defined. Dubreuil (1960a) describes two successive flood waves in the Flakaho watershed (northern Ivory Coast, $9^{\circ} 45^{\prime} \mathrm{N}, 1340 \mathrm{~mm}$ annual rainfall) during major storms. The first of these is rapid and intense, occurring after a lag of $30 \mathrm{~min}$ on this $10 \mathrm{~km}^{2}$ watershed, it is followed by a gentler flood wave $4-6 \mathrm{~h}$ later, composed of water which has infiltrated into the plateau at the edge of the cliff and has returned to the surface through cracks in the ironstone.

(3) Based on field experiments, we define the forest environment as that occupying zones close to the coast of Guinea, Ivory Coast, Cameroon, and a large area of Gabon and Congo. It is also found in New Caledonia, the moutainous zones of the West Indies and French Guiana in South America.

Rainfall is often distributed between two rainy seasons occurring over 6-10 months in the equatorial zone. In many cases subsurface runoff is the major component, in others it is runoff over the extensive surfaces of saturated soils of the plains and valley floors. Despite almost continuous humidity, the intensity of these flows still depends on degree of soil staturation before rain. Forest vegetation, lower shrub strata and leaf litter protect the soil and act as a brake upon the transformation of rainfall into flow. The intensity of tropical storms limits the effectiveness of this protective role.

A steady flow is observed in all small streams, with the exception of some cases where rainfall is less than $1400 \mathrm{~mm}$, as in central Ivory Coast. Close to the divides and where gauging stations are located above the water table, small streams dry up in the long dry season from August to November (e.g. in Guiana) despite annual rainfall of $3400 \mathrm{~mm}$ because each stream drains only a few ha and is not cut sufficiently deep into the weathered material (Roche, 1979).

\section{OBSERVATION. OF THE MAIN PHYSICAL PHENOMENA IN THE FIELD}

In this section physical phenomena related to runoff generation are studied on the basis of: (a) field observations made during the rainy season; (b) measurements carried out at gauging stations, and (c) analyses conducted on these measurements to evaluate annual flow, or the ten-year flood, or to better comprehend the mechanisms involved; these are dealt with as follows: (1) the types of direct and delayed runoff and conditions prior to their occurrence; (2) runoff and infiltration; (3) the roles of the soil surface crusts and of vegetation; (4) the types of statistical experimental relationships between rainfall and runoff; (5) the form of floods and the unit hydrograph; (6) degradation of the drainage network in semi-arid environments; and (7) . conditions favourable for the maintenance of a steady base flow. 


\section{Types of runoff and conditions for their occurrence}

Surface runoff was observed very clearly in most small watersheds during heavy rain, especially close to gauging stations. Surface runoff occurs almost inevitably in arid conditions and is still frequent under more humid tropical conditions. However, where annual rainfall exceeds $1200-1400 \mathrm{~mm}$ and the vegetation is growing very rapidly at the height of the rainy season, runoff is observed less frequently. (Runoff can often be observed between tufts of grass where microravines can form in bare soil:) Where the vegetation is thin (footpaths, road, cattle tracks, cultivated areas) there is almost always some runoff. Runoff cannot easily be observed in the rainforest.

Rainfall is classified by whether or not runoff occurs at the gauging station. A limiting curve of rainfall resulting in runoff may be plotted on a graph of rainfall depth against antecedent moisture index of the watershed soils (Fig. 1). This limiting rainfall represents interception by vegetation and infiltration until precipitation exceeds infiltration somewhere in the watershed. It is interesting to note that in most of the watersheds studied, the limiting curve is steady throughout the rainy season, indicating that the process of runoff generation also remains steady; some exceptions are given in a following section.

In most watersheds, when flow is quite often due to direct runoff, researchers have considered the antecedent moisture index at the time $t_{\mathrm{a}}$ which distinguishes current precipitation from previous precipitation. When the index selected is either the base flow observed at the beginning of the shower or an equation which associates the previous rainfall $\left(P_{\mathrm{a}}\right)$ with the time at separating them from current rainfall, flow may be attributable to causes other than direct runoff. This applies to equations of the type: $\sum P_{\mathrm{a}} \mathrm{e}^{-n t_{\mathrm{a}}}$.

In the first case the limiting rainfall of all watersheds with similar moisture conditions may. be compared by taking $t_{\mathrm{a}}=1$ day. Table 1 illustrates that the limiting rainfall increases from a minimum in the semi-arid environment through the other environments, and from sandstones and schists to some granitic formations; these levels of limiting rainfall often represent a large proportion of a tropical storm. Similar results are also observed under simulated rainfall on $5 \times 10 \mathrm{~m}$ plots (Lafforgue, 1977) in semi-arid Upper Volta as well as on the bare forest soil along the Ivory Coast coastal zone.

All these experiments show quite well that limiting rainfall - or initial rainfall before ponding and runoff - is a function which increases with the soil moisture deficit and can be expressed as:

$P_{1}=K\left(1-\mathrm{e}^{-n t_{\mathrm{a}}}\right)$

where $K$ and $n$ are constants dependent upon the environment.

When a tropical storm exceeds limiting rainfall, runoff occurs and leads to direct runoff in the lower part of the plot or at the outlet of the watershed. However, this runoff does not always occur over the whole watershed but 

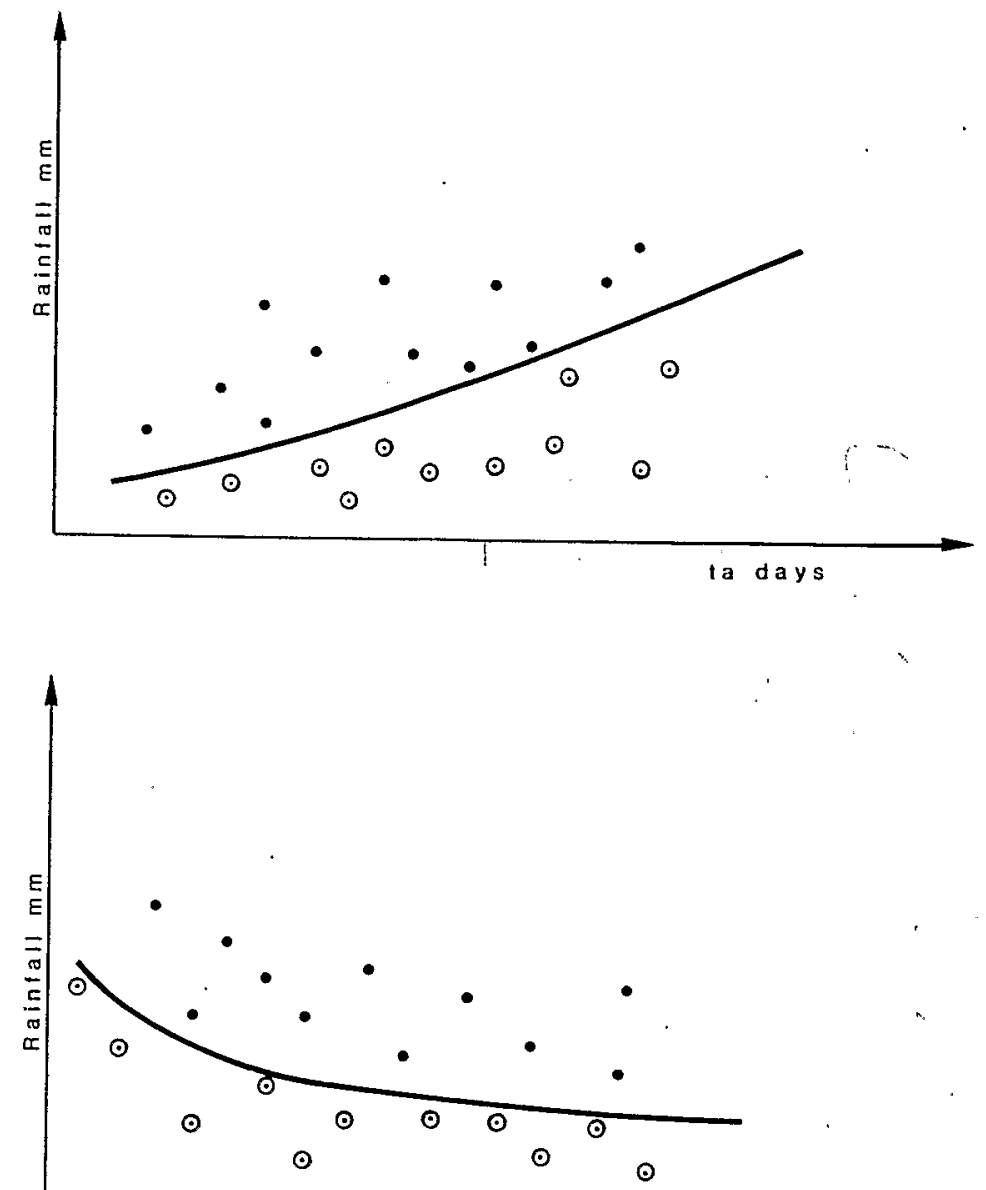

I.h or oo

- Storm rúnolt

○ Storm Without runotl

La Duration between the perious rainlall and the current one

Ih Antecedent precipitation Index

Qo Minimum discharge belore the current ralniali

Fig. 1. Limiting for runoff and antecedent precipitation index.

only given certain conditions of soils and morphology. This is illustrated in the arid and semi-arid environments where sparse vegetation does not influence runoff. Table 2 summarizes the occurrence of flow in relation with the 
TABLE 1

Minimum rainfall to produce runoff - mean values observed ( $\mathrm{mm}$ )

\begin{tabular}{|c|c|c|c|c|c|c|}
\hline \multirow{2}{*}{$\begin{array}{l}\text { Geologic } \\
\text { substratum }\end{array}$} & \multicolumn{6}{|l|}{ Environment } \\
\hline & $\begin{array}{l}\text { Arid and } \\
\text { semi-arid }\end{array}$ & $\mathrm{mm}$ & Tropical & $\ddot{m m}$ & Forest & $\mathrm{mm}$ \\
\hline sandstones & $\begin{array}{l}\text { outcropping rock } \\
\text { lithosols }\end{array}$ & $3-7$ & $\begin{array}{l}\text { well drained } \\
\text { sloping soils }\end{array}$ & $12-13$ & & \\
\hline schists & $\begin{array}{l}\text { lithosols, clay } \\
\text { soils (regs) }\end{array}$ & $3-7$ & $\begin{array}{l}\text { well drained and } \\
\text { well watered } \\
\text { sloping soils }\end{array}$ & $5-8$ & $\begin{array}{l}\text { hydromorphic soils } \\
\text { gley soils }\end{array}$ & $9-12$ \\
\hline granites & $\begin{array}{l}\text { glacis, granitic sands } \\
\text { clay-sandy soils }\end{array}$ & $9-14$ & $\begin{array}{l}\text { well drained and } \\
\text { watered sloping soils }\end{array}$ & $7-10$ & ferrallitic soils & $15-20$ \\
\hline & & & $\begin{array}{l}\text { Low gradient, } \\
\text { bad drainage }\end{array}$ & $9-12$ & & \\
\hline $\begin{array}{l}\text { granites/schists under } \\
\text { thick indurated laterite } \\
\text { tableland }\end{array}$ & & & well watered & $15-18$ & & \\
\hline
\end{tabular}

${ }^{a}$ Except if there are boulders. 
TABLE 2

Occurrence of flow in the semi-arid and arid environments

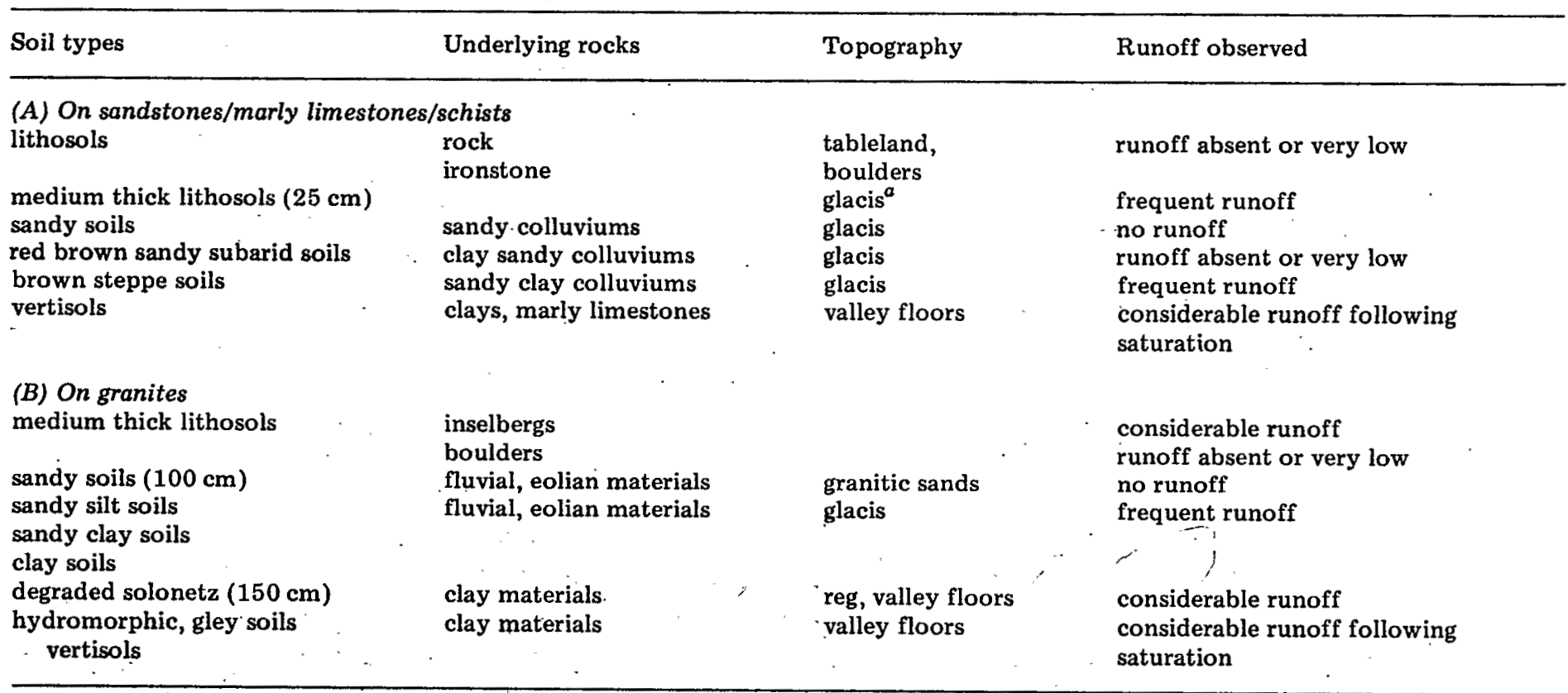

"Or "Sloping". 
main geomorphological formations and soils commonly found along the length of a stream in watersheds with the following substrata: Sandstones, limestones, schists or granite, gneiss and migmatites.

Very early in the rainy season considerable runoff can be observed on the following soil formations: Lithosols $20-25 \mathrm{~cm}$ thick on glacis or pediments; brown steppe soils; sandy silt soils and sandy clay soils on fluvial or aeolian colluvia (over granites). Evidence of this runoff if given by Vuillaume (1969) who compared the runoff potential of five microwatersheds $(3-10 \mathrm{ha})$ in eastern Niger at Kountkouzout $(400 \mathrm{~mm}$ annual rainfall, sandstones and marly limestones, latitude $15^{\circ} \mathrm{N}$ ). This work shows that the surface runoff ratios of severe storms range from 30 to $75 \%$ in line with the extent of the different soil types.

As far as granitic substrata are concerned (gneiss, migmatites) Rodier (1975) provides further proof of the conclusions of Table 2 by classifying runoff potential of small watersheds in eastern Chad $(300-500 \mathrm{~mm}$ annual rainfall, latitude $12^{\circ}-14^{\circ} \mathrm{N}$ ). High runoff is observed on the clay regs and the solonetz soils of the valley floors as well as on glacis covered with sandy clay soils which show surface runoff ratios as high as $\mathbf{7 5 \%}$ following severe storms; these ratios fall to $20 \%$ and even $5 \%$ on coarse and granitic sands.

Table 3 presents the occurrence of flow in relation with the main soil types found on granites in the humid tropical environment. The sequence of soils along the watershed is slightly different to that noted for the semiarid environment; soil textural features are the most pronounced modifications. The laterite tablelands are covered with very deep and permeable soils; leached soils with deep clay deposits are formed on the slopes. This development results from high rainfall and intense weathering of rock. Runoff is delayed until the upper horizon of the soil reaches field capacity and is called subsurface runoff: This occurs sooner and lasts longer when rainfall is heavy. It is difficult to distinguish direct from subsurface runoff at the outlet of a watershed, however small the watershed may be; except when particular circumstances of topography permit them to be distinguished over time (as at Flakaho, Dubreuil, 1960a) or when the absence of soils suitable for runoff in low rainfall areas allows the subsurface runoff to occur alone (as at Ngola, see Tixier, 1953). In these cases lag times or rise times of observed floods are considerably increased by subsurface runoff.

In the forest environment only the summits and the slopes are covered with unsaturated ferrallitic soils. The water relations of these ferrallitic soils are somewhat complicated. However, detailed analysis of their threedimensional arrangement and their micro-morphology enabled Boulet et al. (1979) to determine their role in the process of runoff generation in a series of experimental watersheds of 1-2 ha on mica schists in Guiana $(3400 \mathrm{~mm}$ annual rainfall, latitude $4^{\circ} \mathrm{N}$ ). These ferrallitic soils normally show a deep clay horizon with low porosity under a sandy clay upper horizon, $20 \mathrm{~cm}-$ $1 \mathrm{~m}$ thick. This horizon is sometimes impermeable and very compacted; occasionally permeability is low but sufficient to allow water to drain 
TABLE 3

Occurrence of flow on granites in the tropical environment

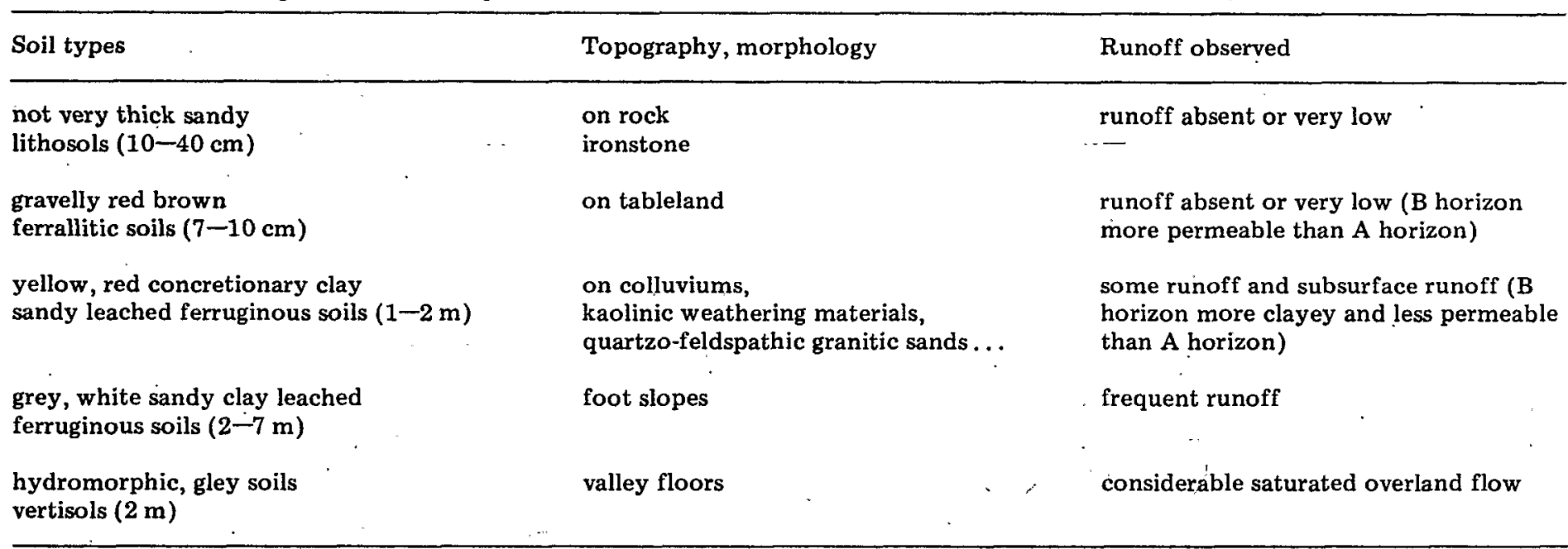


through the upper horizon. This difference determines whether the soils drain laterally - this is subsurface runoff - or freely to the water table.

Runoff cannot easily be observed under forest, due to the thick leaf litter. In Guiana, Blancaneaux (1973) observed runoff both on footpaths where litter had been compacted or cleared, as well as under litter. In both cases runoff was very slow and so it was not possible to make separate observations of surface and subsurface runoff at the watershed outlet in these zones. However, these can be identified on experimental plots, as was shown by Roose (1979) in a comprehensive synthesis of the dynamics of ferrallitic soils in which he notes that the two types of runoff produce similar average annual values when related to rainfall: $1-2 \%$ on freely drained soils in Ivory Coast (2100 $\mathrm{mm}$ annual rainfall), and 5-15\% on undrained soils in Guiana ( $3400 \mathrm{~mm}$ annual rainfall).

If there is a decrease in rainfall, net runoff may be observed only on the hydromorphic soils of the valley floors. These normally porous soils become impermeable only in the height of the rainy season when the groundwater rises to the surface so that, although runoff is almost total, it is mistaken for overflowing groundwater following severe storms. This is the case on the freely drained soils under savanna at the edge of the forest (central Ivory Coast, $1200 \mathrm{~mm}$ annual rainfall in two seasons) and in the watershed of Sakassou where Lafforgue (1982) showed that no runoff occurs under simulated rainfall of $120 \mathrm{~mm} \mathrm{~h}^{-1}$, while runoff attained $80 \%$ of input under simulated rainfall of $30 \mathrm{~mm} \mathrm{~h}^{-1}$ on hydromorphic soils. This last example shows the exceptional or unstable behaviour of watersheds in the rainy season. This was also mentioned above when comparing limiting rainfall and antecedent time to the previous storm.

Such behaviour is generally observed in the humid tropical zone where low rainfall is distributed over many months, sometimes concentrated in two rainy seasons. Such situations occur either in watersheds with very thick and permeable soils or watersheds where vertisols and hydromorphic soils of valley floors predominate, or in watersheds where a permanent water table rises to the surface at the end of the rainy season.

Several examples of such situations are listed in Table 4. Apart from the limiting rainfall, soils must be filled with an amount of water which is represented by the total of antecedent rainfalls $\left(P_{a}\right)$ before runoff occurs. For example, Dubreuil (1960b) has noted that runoff cannot occur in the Lhoto watershed in those years when $P_{a}$ does not reach the required thresholds of minimum water content.

Once the conditions for runoff generation have been met, watersheds with very permeable soils will experience mainly subsurface runoff (rise time of $4-5 \mathrm{~h}$ over $10-15 \mathrm{~km}^{2}$ ), while on vertisols or in watersheds where groundwater rises to the surface, the consequence will be almost total saturated overland flow (Casenave, 1978).

Therefore we must conclude with Hewlett and Hebbert (1967) and Dunne (1983) that in tropical zones several types of runoff can occur in the same 
TABLE 4

Minimum rainfall to produce runoff (1) and antecedent moisture index (2)

Structure of the watershed

Beginning of the rainy season

$(1)(\mathrm{mm})(2)$
Middle and end of the rainy season

$(1)(\overline{\mathrm{mm}})(2)$

(1) Very permeable thick soils

granitic boulders, very thick granitic

sand, sandy soils on colluviums

(Lhoto, Bénin, $1100 \mathrm{~mm} \mathrm{yr}^{-1}$ with 2 seasons)

thick sandy leached ferruginous soils with

low gradient $+15 \%$ of gley soils

(Tiapalou, Bénin, $1300 \mathrm{~mm} \mathrm{yr}^{-1}$ within 6 months)

$\begin{array}{rrrr}10 & \text { if } \Sigma_{1}^{30} P_{\mathrm{a}} & >150 \mathrm{~mm} & 10 \\ 20 & & >100 \mathrm{~mm} & 20 \\ 40 & & >60 \mathrm{~mm} & 40 \\ 50 & \text { if } \Sigma_{1}^{90} P_{\mathrm{a}} & >500 \mathrm{~mm} & 10\end{array}$

if $\begin{aligned} \Sigma_{1}^{30} P_{\mathrm{a}} & >150 \mathrm{~mm} \\ & >100 \mathrm{~mm} \\ & >60 \mathrm{~mm}\end{aligned}$

$\left(t_{\mathrm{a}}=1\right.$ day $)$ or $\Sigma_{1}^{30} P_{\mathrm{a}}>250 \mathrm{~mm}$

20

$\left(t_{\mathrm{a}}=10\right.$ days $)$ or $\Sigma_{1}^{30} P_{\mathrm{a}}>150 \mathrm{~mm}$

(2) Vertisols

$55 \%$ of hydromorphic soils in the valley

floors + very permeable ferrallitic soils

(Sakassou, Ivory Coast, $1200 \mathrm{~mm}$ within 2 seasons)

vertisols on marly shales

(Lac Elia, Togo, $1050 \mathrm{~mm}$ within 2 seasons)

35 with $I H \leqslant 25$

$I H=\Sigma_{\mathrm{I}}^{45} P_{\mathrm{a}} \cdot \mathrm{e}^{-0,10 t_{\mathrm{a}}}$

40 if $\Sigma P_{\mathrm{a}}=350 \mathrm{~mm}$

15

,

(3) Groundwater rising to the surface

lithosols and very thick sandy leached

ferruginous soils on sandstones

(Sanguéré, Cameroon, $1050 \mathrm{~mm}$ per 5 monṭhs)

gravelly red tableland soils,

thick clay sandy ferrallitic soils on

granitic sands (Korhogo, Ivory Coast,

$1400 \mathrm{~mm}$ per 6 months)

$$
\begin{aligned}
& 30-50 \text { if } \Sigma P_{\mathrm{a}} \leqslant 400 \mathrm{~mm} \quad \quad 25 \quad \cdot 400<\sum P_{\mathrm{a}}<800 \mathrm{~mm} \\
& 30 \text { if } Q_{0}=25 \mathrm{ls}^{-1} \quad 15 \quad \text { if } Q_{0} \geqslant 125 \mathrm{ls}^{-1} \\
& \text { or } I H=10 \quad \text { or } I H \geqslant 70
\end{aligned}
$$

Note: $\Sigma_{1}^{30} \cdot P_{\mathrm{a}}=$ total of antecedent rainfalls on 30 days; $t_{\mathrm{a}}=$ duration from previous rainfall in days; $I H=$ antecedent moisture index; and $Q_{0}=$ minimum discharge before rainfall. 
watershed, that the source areas of each type may amount to only part of the watershed and that these source areas may vary throughout the rainy season when, for example, groundwater rises to the surface.

\section{Runoff and infiltration}

Once conditions for the occurrence of runoff have been met, the volume of that runoff, depends only on the intensity and distribution of the storm under consideration, and the depth of water that falls; this has been demonstrated using simulated rainfall with constant intensity. Lafforgue (1977) confirms that Horton's exponential decay of infiltration gives the best representation of the physical processes observed on plots. Given rainfall of constant intensity over a long period of time, runoff reaches a maximum when the infiltration rate is at its minimum (Fig. 2). The variation of infiltration with time, $F(t)$, is given by:

$F(t)=F_{\mathrm{n}}+\left(F_{\mathrm{o}}-F_{\mathrm{n}}\right) \mathrm{e}^{-k t}$

$F(t)$ can be measured, and the parameters $k$ and $F_{0}$.calculated from measurements of simulated rainfall, maximum runoff, volume of water stored on the surface, etc. Using simulated rainfalls with variable intensity and antecedent moisture indices it may be shown that $F_{\mathrm{o}}, F_{\mathrm{n}}$ and $k$ vary with these two main parameters and that $F_{\mathrm{n}}$ is not a real constant even if it varies only slightly. Lafforgue (1977) ascribed its lack of consistency with Horton's equation to the heterogeneity of plot soil and vegetation cover, but this has still to be confirmed.

Soil infiltration capacity decreases with time under real rainfall of variable intensity, whether it falls on a plot or a small watershed. This has been clearly observed in tropical zones where short and heavy showers often consist of several well-defined strong-intensity squalls separated by lulls of low intensity. If the watershed is small, runoff also shows well-defined peaks. Using the unit hydrograph method, it is possible to see that the limiting lower intensity of the rainfall excess, shows an appreciable decrease from one squall to the next (Dubreuil, 1974). However, this limiting lower intensity corresponds to the mean infiltration during the squall $\bar{F}$. When the antecedent moisture index is low, and rainfall intensity is high, $\bar{F}$ is also high, it decreases as the duration of rainfall increases. Therefore, the infiltration capacity and initial rainfall preceding runoff show similar behaviour on both plot and small watershed. Saturated overland flows show. the same physical behaviour on vertisols, gley soils of valley floors and on soils with shallow groundwater, except, that the parameter $F_{\mathbf{n}}$ is equal to zero when the soils are waterlogged and groundwater rises to the surface. At the height of the rainy season, such soils dry out very slowly at an average rate equivalent to an evapotranspiration rate of about $1 \mathrm{~mm}$ per day. Consequently saturation occurs rapidly during a single shower, as soon as rainfall exceeds the limit set by $t_{\mathrm{a}}$. Subsurface runoff was observed on plots as well as small watersheds; 


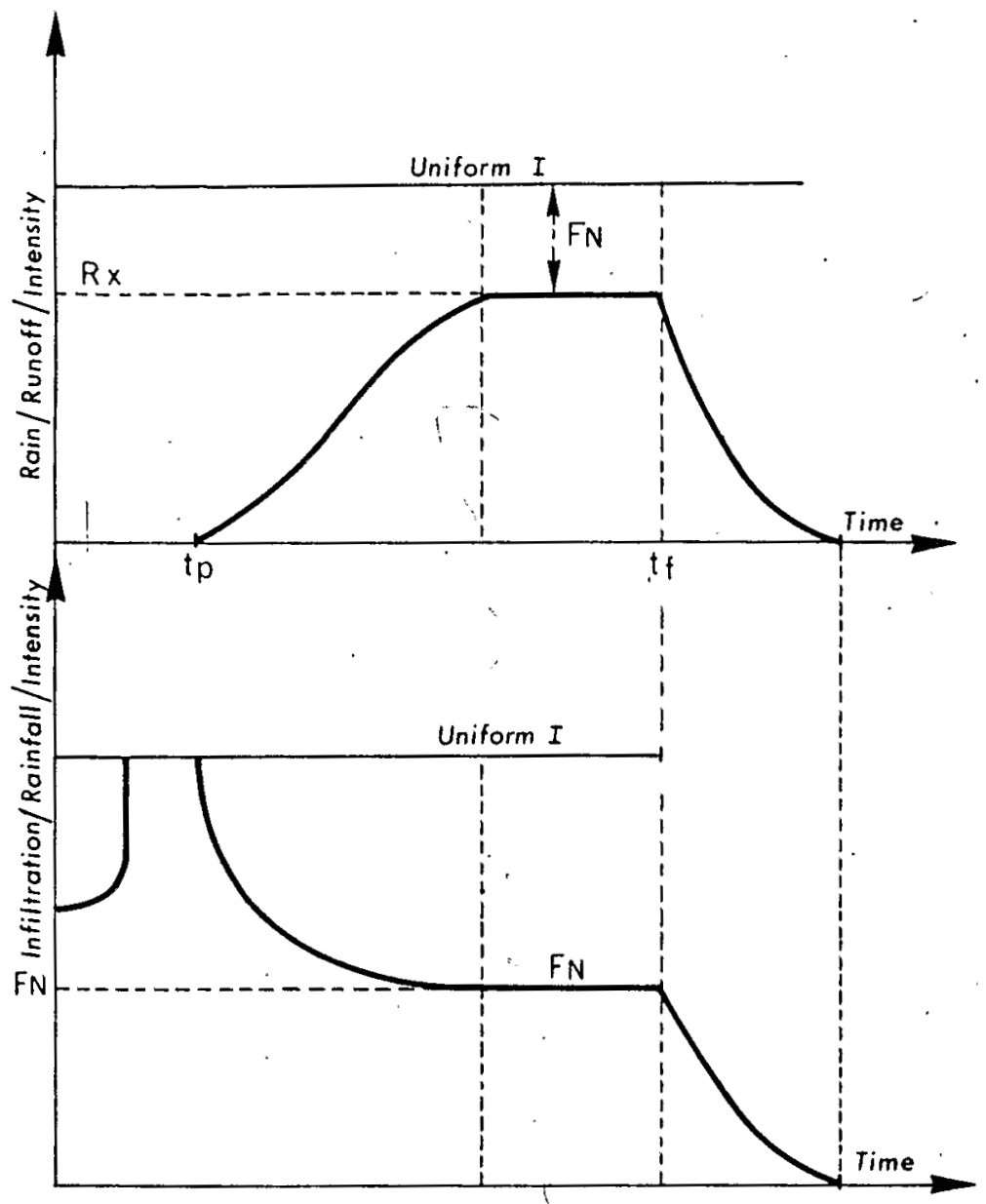

$R \times$. Maximum runoft intensity

tp. Ponding time

FN. Minimum infiltration rate.

$t f$ : End of rainfall

Fig. 2. Relationships between rainfall, runoff and infiltration under simulated rainfall.

however, no alteration has been noted in the physical process or depth of runoff as the area increases. Field research is needed to better define the occurrence and hydraulic behaviour of subsurface runoff through the soil on its way to a stream. 


\section{Soil surface crusts and vegetation}

Runoff generally occurs when a certain depth of limiting precipitation is reached. This limit is lower for arid and semi-arid environments than for the other environments. The explanation of this is partly the role of interception and control by vegetation, which is significant except in the arid environment. Paradoxically this limit also depends on the soil-antecedent moisture which normally remains rather low in a semi-arid environment. The existence of soil surface crusts - also known as sealing crusts - are the main cause of the lowest limits for runoff occurring on small watersheds in a semi-arid environment, and depth of soil is a contributing factor.

Surface crusts are formed once the first showers occur and especially where the surface layer includes clay, and on all bare soils or soils inadequately protected by sparse vegetation (the consequence of 6-9 dry months). In Niger and Upper Volta, Valentin (1981) showed that: (1) several types of weathering surface crusts occur on clays and of laminar and compacted deposits on sandy clay soils; (2) these surface crusts include three micro-horizons: The uppermost of these is sandy and unconsolidated, the middle one is sandy and sticky with vesicular pores, and the lower horizon is plasmic; and (3) the micro-structure of these surface crusts leads to a decrease in soil porosity and saturated conductivity.

When the rainy season commences (between mid-July and late August) the herb layer springs up rapidly, achieving its maximum growth rate within two weeks. Using a sprinkling infiltrometer on $1 \mathrm{~m}^{2}$ plots in Upper Volta (450 $\mathrm{mm}$ annual rainfall) Chevallier (1982) showed that the presence of a thick herb layer increases limiting rainfall, infiltration and surface storage following rain, an effect apparently related to surface roughness of the soil as vegetation inhibits the development or preservation of the surface crusts.

On the watersheds, the limiting rainfall value does not increase in the rainy season, probably because vegetation cover is rarely continuous; however, increasing roughness is often observed downstream and rainfall-runoff relationships or the forms of the hydrographs may vary, though this is infrequently the case.

Vegetation also includes crops, where the main factors are furrowing and tillage. Using simulated rainfall, Collinet and Valentin (1979) showed the favourable effects of furrowing on limiting rainfall and on runoff, but these are ephemeral if certain conditions of soil and soil preparation are not met (Table 5). If all favourable conditions are present, these authors point out that available soil water can be increased from 40 to 100 and even $200 \mathrm{~mm}$, which permits more reliable dry farming and reduces erosive runoff.

On the other hand, the same authors note that furrowing tends to increase runoff in the tropical zone of northern and central Ivory Coast, for the following reasons: (1) it destroys the surface macropores of the tableland red soils; thus inhibiting infiltration, (2) the thick, almost permanent vegetation is temporarily removed; and (3) roughness of soil is reduced when surface gravels are buried. 
TABLE 5

Influence of furrowing and soil surface conditions on limiting rainfall and runoff

\begin{tabular}{lll}
\hline Soil furrowing & $\begin{array}{l}\text { On the limiting rainfall } \\
\text { Positive and increasing } \\
\text { effect }\end{array}$ & $\begin{array}{l}\text { On runoff } \\
\text { Negative and decreasing } \\
\text { effect }\end{array}$ \\
\hline $\begin{array}{l}\text { formation of surface crusts } \\
\text { (first rains) }\end{array}$ & effect canceled & effect canceled \\
$\begin{array}{l}\text { soil covered with mulch or } \\
\text { ridge soil + presence of coarse } \\
\text { elements at the surface }+ \\
\text { presence of stable aggregates }\end{array}$ & effect maintained & effect maintained \\
\hline
\end{tabular}

Note: Soils surface conditions (under the line across) modify the impact of soil furrowing.

Camus and Berthault (1972) come to rather similar conclusions. The permeability of the soils in the watershed of Korhogo (granites, $1400 \mathrm{~mm}$ of annual rainfall) was measured; infiltration rates were very high under thick tree vegetation and on the summits of recent ridges, and very low on bare soils or on old fallow under sparse grass.

These few examples clearly show the importance of the surface texture of the soil, tillage and type of vegetation. These effects act together to determine the hydraulic behaviour of the soil-cover complex. Using the sprinkling infiltrometer to test this behaviour systematically may be a more effective line of research than using physical equations which seem to be too complex and badly defined to model the behaviour of such soil-cover complexes, although the method is purely experimental. Casenave et al. (1982), in a line of research that deserves further study, uses this method in the forest zone of the Ivory Coast and succeeds in determining rather good and simple relationships between the amount of infiltrating water and the soil texture and structure. It is now possible to make considerable progress into the interactions between soil surface, tillage and vegetation cover and to generalize from them, provided that researchers are careful to include all parameters likely to influence the field experiments.

\section{Quantitative experimental relationships between runoff and rainfall}

Studies made on representative basins have aimed generally at determining extreme floods caused by storms of selected frequency (for example, the ten-year flood). Consequently analytical relationships were first established using the parameters measured in the course of the storm-flood events.

These relationships give either the runoff coefficient $\left(K_{\mathrm{r}}\right)$ or the depth of surface runoff $\left(R_{r}\right)$, which in most cases includes any subsurface runoff, as functions of the precipitation and the antecedent moisture index. They are generally shown graphically, using either mean rainfall $(\bar{P})$ or the useful 

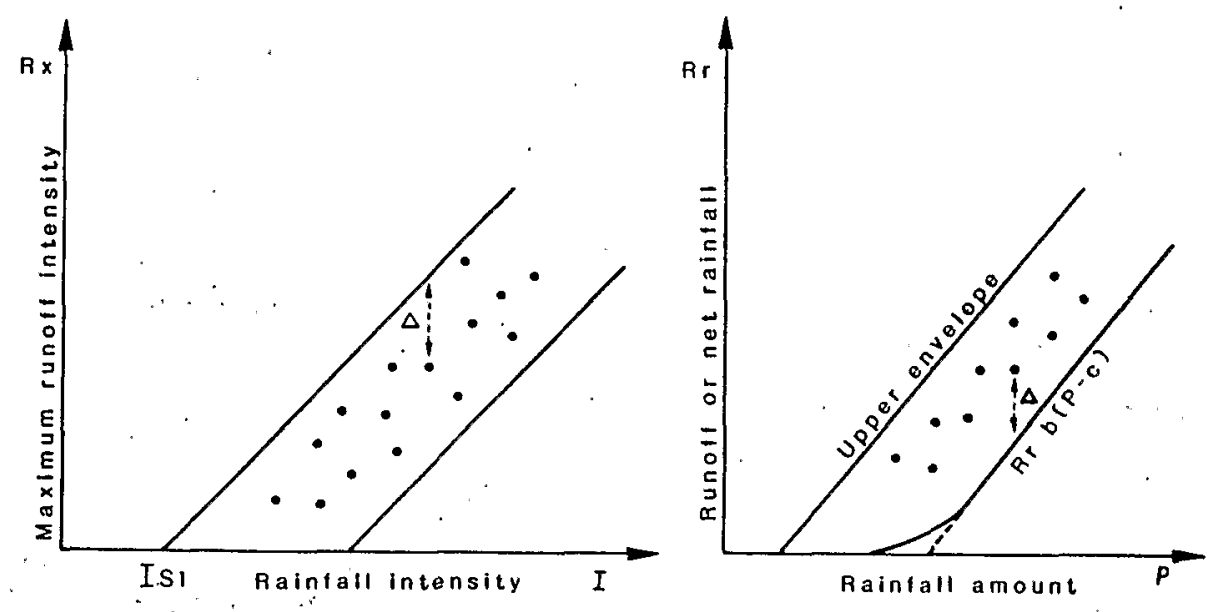

- Storm event

$\Delta$ Depend on 1.h antecedent precipitation index

Is 1 Minimum rainfall Intensity to produce runolf

b.c Adjustment parameters

Fig. 3. Relationships between rainfall and runoff for storm events.

rainfall $\left(P_{u}\right)$ which is the useful fraction of rainfall with intensity higher than a threshold $S$ which ranges from 10 to $20 \mathrm{~mm} \mathrm{~h}^{-1}$ in different examples.

These relationships are most often linear and expressed in the following form: $R_{\mathrm{r}}=b\left(P_{\mathrm{u}}-c\right)$ when runoff is considerable. They can also be expressed in parabolic form (Fig. 3); in this case, runoff is either less important or is highly dependent on soil moisture.

In this first curve, deviations $\Delta R_{\mathrm{x}}$ are generally accounted for by the antecedent moisture index, the most elaborate expression of which is:

$I_{\mathrm{h}}=\sum_{1}^{\mathrm{n}}\left(P_{\mathrm{a}}-R_{\mathrm{a}}\right) \mathrm{e}^{-\alpha t_{\mathrm{a}}}$

where $n$ is the number of days before the event; $P_{\mathrm{a}}$ is the antecedent rainfall observed at time $t_{\mathrm{a}} ; R_{\mathrm{a}}$ is the depth of surface runoff in the course of the event $P_{\mathrm{a}}$; and $\alpha$ is the adjustment parameter.

Maximum storm intensity has also been studied but the effect of this on $\Delta R_{\mathrm{r}}$ is generally low.

Comparison between all relationships of the type $R_{\mathrm{r}}=f\left(P, I_{\mathrm{h}}\right)$, did not 
lead to any correspondence with the ranges of the limits of runoff (Table 1) or the climatic zones. Likewise, the parameter $\alpha$ varies from 0.10 to 1 in the various studies and does not seen: to be clearly related to the rainfall pattern. It is important to note that no study shows a change in the relation $R_{\mathrm{r}}=$ $f\left(P, I_{\mathrm{h}}\right)$ during the rainy season. This tends to confirm the apparent overall stability in the behaviour of flow processes already observed.

Another significant observation will perhaps modify this assertion. Outside very small and well studied homogeneous watersheds, the relationship $R_{\mathrm{r}}=f\left(P, I_{\mathrm{h}}\right)$ shows considerable and unexplained deviations $\Delta R_{\mathrm{r}}$ which can be ascribed to inaccurate measurements of discharge and rainfall, and also to the spatial heterogeneity of the watershed.

It is very important to note that the nature of these relationships $R_{\mathrm{x}}=$ $f\left(P, I_{\mathrm{h}}\right)$ based on watersheds data analysis, is confirmed experimentally under simulated rainfalls on plots of $1-50 \mathrm{~m}^{2}$ in the three types of environment and that they are also expressed in the same numerical form (Lafforgue, 1977; Casenave, 1982, Chevallier, 1982). Using the maximum steady flow intensities, reached with heavy simulated showers, $R_{\mathrm{x}}$ for runoff and $I$ for rainfall, these authors show that:

$R_{\mathrm{x}}=K\left(I-I_{\mathrm{s}}\right)$

where $I_{\mathrm{s}}$ is the limiting runoff intensity ranging from $I_{\mathrm{s} 1}$ and $I_{\mathrm{s} 2}$.as related to the antecedent moisture index $I_{\mathrm{h}}$ (Fig. 3). It will be seen that the limit $I_{s 1}$ is related to the threshold $S$ used for calculation of useful rainfall $P_{\mathrm{u}}$ in watersheds. Moreover, Lafforgue (1977) shows that the relation $R_{\mathrm{x}}(I)$ can be expressed in parabolic form when the $50 \mathrm{~m}^{2}$ plot is heterogeneous with respect to infiltration capacity.

It was observed on several occasions that the semi-arid environment was generally the most stable in relation to the processes of flow, with runoff prevailing. In semi-arid Upper-Volta $\left(14^{\circ} 30^{\prime} \mathrm{N}\right)$, Chevallier (1982) finds a linear relationship:

$R_{x}=a P_{\mathrm{u}}+b I_{\mathrm{h}}-c$

on soils given simulated rainfalls with the $1 \mathrm{~m}^{2}$ sprinkling infiltrometer.

Finally, it will be remembered in this connection that the global conceptual model of Girard (1975a), used successfully in more than 30 semi-arid watersheds, is based only on the linear system $R_{r}=K\left(P-P_{0}\right)$ related to the system $R_{\mathrm{x}}(I)$ where $P_{0}$ depends on the antecedent moisture index and field capacity, while $K$ is related to a surface runoff ratio.

Therefore we may conclude that the type and shape of the relationship which transforms rainfall into flow $R_{\mathrm{r}}=f\left(P, I_{\mathrm{h}}\right)$ does not change with size of watershed up to several $\mathrm{km}^{2}$ and that the relationship tends to be linear when surface runoff predominates, the soil is homogeneous and the area of the watershed is not too large.

Lafforgue (1982) corroborates this by giving the high envelope curves $R_{\mathrm{r}}=k\left(P_{\mathrm{u}}-P_{0}\right)$ of the small watersheds $\left(0.5 \mathrm{~km}^{2}\right)$ at Sakassou in the 
Ivory Coast, where $K$ represents the proportion of hydromorphic soils on the valley floors which give rise to almost total runoff when saturated $\left(P_{0}\right.$ ranges from 1 to $2 \mathrm{~mm}$ ).

\section{The form of floods and unit hydrographs}

As shown previously, surface runoff occurs from the soils that become saturated, subsurface runoff occurs in others when a certain water holding capacity is exceeded. Moreover, the behaviour of a watershed can be influenced by surface crusts and vegetation growth.

Under such conditions, it might be thought that observed floods would assume very irregular forms, and that the unit hydrograph method would often be inappropriate. However, a comprehensive survey of all the floods from a watershed shows that their heterogeneity is due mainly to that of showers and storms.

$\therefore$ In the tropics, storms are convective covering small areas, except in the equatorial zone at the height of the rainy season. Generally, it is impossible to define a typical form of flood for watersheds larger than $100 \mathrm{~km}^{2}$. In watersheds from 5 to $50 \mathrm{~km}^{2}$ and taking only those storms above a minimum intensity much greater homogeneity is observed.

Consequently researchers in almost all the representative basins between 5 and $50 \mathrm{~km}^{2}$, were able to define unit hydrographs with a characteristic rise time $t_{\mathrm{m}}$, as base time $T_{\mathrm{b}}$ and a maximum instantaneous discharge $Q_{\mathrm{x}}$ for a unit volume. However, very few studies mention any change in the form of the unit hydrograph during the rainy season. Some researchers observed that in the semi-arid environment at the beginning of the rainy season, the unit hydrograph was sharper than in August-September, indicating greater. risk of serious flooding. This phenomenon may be accounted for by either: (1) runoff occurring only in a limited part of the watershed at the beginning of the season; or (2) the existence of impervious surface crusts; or (3) plant growth, which reduces surface crusts and checks runoff rate.

The existence of a dry low water channel at the beginning of the season can have an opposite effect by delaying and reducing the peak discharge (Sircoulon, 1964).

All researchers who aimed mainly at evaluating the ten-year flood tended generally to consider only severe floods as events likely to lead to the definition of the unit hydrograph, which certainly accounts for the success of the technique and the stability hydrograph throughout the season.

When very detailed studies are made, less obvious conclusions are drawn. For instance, Camus et al. (1976), who have observed the Korhogo watershed for ten years note that: (a) the unit hydrograph of very severe floods is sharper than that of other floods $\left(Q_{x}=1.00 \mathrm{~m}^{3} \mathrm{~s}^{-1}\right.$ instead of $0.63-0.85$ $\mathrm{m}^{3} \mathrm{~s}^{-1}$ ); (b) the form of the unit hydrograph became smoother over a tenyear study period as a cashew nut forest grew up over $12 \%$ of the watershed an as crops were extended over an additional third of the area, increasing 
from 20 to $50 \%$ of the watershed. Over this period $Q_{\mathrm{x}}$ decreased from 0.85 to 0.63 , while $t_{\mathrm{m}}$ increased from 40 to $50 \mathrm{~min}$. This carefully studied example shows the role of vegetation and how uncertain - outside the semiarid environment - the general applicability of the unit hydrograph can be.

\section{Degradation of the drainage network}

Degradation is observed only in the semi-arid environment, where it is so important that the runoff-rainfall relationship is largely modified when the drained area exceeds a few tens of $\mathrm{km}^{2}$. The distinct low-water channel of the small stream tends to disappear and is replaced by a shifting high-water channel dotted with islands as a lateral flood plain develops. If the geomorphological conditions are favourable, the stream disappears into the flood plain.

The intensity and rapidity of this process of degradation depend on rainfall and soils. Rodier (1975) gave a detailed and exhaustive description of degradation in one environment in his study of flow in the Sahel. We deal with this phenomenon in this paper only because it influences the process of flow by leading to considerable losses in the low-water and high-water channels of medium-size watersheds. These losses are due first to the filling of the pools in a dry low-water channel between storms and to infiltration into the generally sandy sediments. Such losses can range from 300,000 to $1 \times 10^{6} \mathrm{~m}^{3}$ during a flood in a $1200 \mathrm{~km}^{2}$ watershed situated in eastern Chad (latitude $12^{\circ} \mathrm{N}, 800 \mathrm{~mm}$ annual rainfall).

Losses are far greater during severe floods where there are a high-water channel and flood plains. In Mauritania, they range from 10 to $100 \times 10^{3} \mathrm{~m}^{3}$ $\mathrm{km}^{-1}$ in a $1100 \mathrm{~km}^{2}$ watershed (latitude $16^{\circ} \mathrm{N}, 475 \mathrm{~mm}$ annual rainfall) during the ten-year flood; this represents almost $30 \%$ of the total flood volume.

When a stream disappears into its floodplain, the alluvial water table may be replenished, supplying wells throughout the dry season. In eastern Chad, infiltration of $1000-2000 \mathrm{~m}^{3}$ per ha was observed. In the sandy low-water or high-water channels, percolating waters can move slowly downwards into an underflow of negligible discharge. In a large stream in Niger close to Agadés (latitude $17^{\circ} \mathrm{N}, 165 \mathrm{~mm}$ annual rainfall) an injection of salt was used to measure a discharge of $1 \mathrm{~m}^{3} \mathrm{~h}^{-1}$, corresponding to a velocity of $0.5-0.9 \mathrm{~m}$ $\mathrm{h}^{-1}$.

Rapid degradation of the channel pattern in the semi-arid environment leads to considerable flow losses by overflowing, infiltration and evaporation in the low- and high-water channels and floodplains. The downstream transfer of the flow is affected but not the transformation of precipitation into flow, which depends on the morphological conditions of the channels and the depth of the flood. Modelling must take this into account by using real data measurements. 
TABLE 6

Data on selected small watersheds with steady flow in the tropical environment

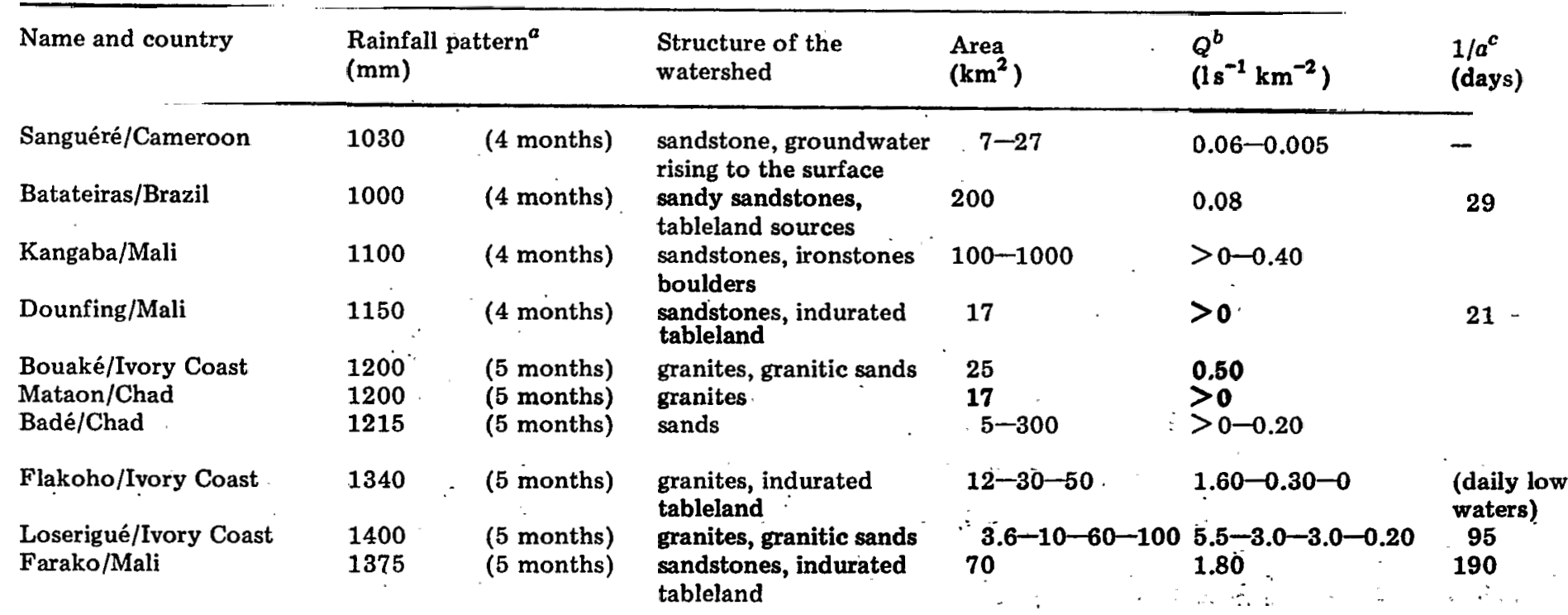




\begin{tabular}{|c|c|c|c|c|c|c|}
\hline Androvakely/Madagascar & 1400 & (5 months) & $\begin{array}{l}\text { granites, migmatites, } \\
\text { strongly weathered schists }\end{array}$ & $5-25$ & $6.10-5.70$ & 250 \\
\hline Comba/Congo & 1475 & $\begin{array}{l}\text { ( } 7 \text { months) } \\
\text { (2 seasons) }\end{array}$ & $\begin{array}{l}\text { clay sandstones, schists, } \\
\text { marly limestones }\end{array}$ & $\begin{array}{l}5 \\
1\end{array}$ & $\begin{array}{l}6.10 \\
0\end{array}$ & \\
\hline Sara/Togo & 1600 & (6 months) & quartzites, schists & 30 & 3.80 & \\
\hline Boundjouk/Cameroon & 1600 & (7 months) & basalts, ironstone & $2-20$ & $2.40-1.70$ & \\
\hline Mayo Rem/Cameroon & 1600 & (7 months) & granites & 1 & 3.0 & . \\
\hline Kandala/Guinéa & .1700 & (5 months) & $\begin{array}{l}\text { schists, ironstone on } \\
\text { tableland }\end{array}$ & $25-50$ & $0-0.08$ & \\
\hline Timbis/Guinéa & 1700 & (5 months) & sandstones & 200 & 9.0 & \\
\hline $\begin{array}{l}\text { N'Gola/Central } \\
\text { African Republic }\end{array}$ & 1600 & (6 months) & $\begin{array}{l}\text { strongly weathered } \\
\text { quartzites }\end{array}$ & 27 & 3.0 & $\begin{array}{l}\text { (Daily low } \\
\text { waters) }\end{array}$ \\
\hline Douni/Ivory Coast & 1630 & (5 months) & granite gneiss & $5-30-100$ & $>0$ & $25-45$ \\
\hline
\end{tabular}

${ }_{b}^{a}$ Rainfall pattern: Mean annual depth $P$; number of months $>10 \%$ of $P$.

${ }^{b} Q\left(1 \mathrm{~s}^{-1} \mathrm{~km}^{-2}\right)$ : Lowest mean monthly discharge (with certain exceptions).

c 1/a (day): Inverse exponential depletion coefficient.

Successive values in 5 th column (on each line) are related to successive values in 4 th column.

Value $>0$ in 5 th column means that lowest mean monthly discharge is not equal to zero. 
Conditions favourable for the occurrence of a steady base flow

When describing the main characteristics of flows in the three environments under consideration, we made in a previous section some comments on the conditions for the occurrence of a steady base flow. It is difficult to define, a priori, general principles concerning steady base flows of very small streams. However, an approach was attempted using all representative basins larger than $1 \mathrm{~km}^{2}$ situated in the humid tropical environment and those without steady flow situated in the forest environment, in order to discover which factors distinguish a watershed with steady flow from one without. The parameters used for this comparative analysis were as follows: (1) a mean monthly discharge corresponding to the lowest month $q$ expressed in $1 \mathrm{~s}^{-1} \mathrm{~km}^{-2} ;(2)$ a depletion coefficient $1 / a$ expressed in days and derived from the equation $Q=Q_{0} \mathrm{e}^{-a t}$; (3) a rainfall pattern represented by the mean annual depth $P$ and the average number of months receiving more than $10 \%$ of $P$; an equatorial pattern $(E)$ was distinguished as a pattern with two wet seasons; and (4) the parent rock, its weathering materials and the existence of a permanent water table.

Approximately 40 representative basins were selected and compared. The parameters selected for the basins with steady flow are shown in Table 6.

The annual depth of rainfall $P$ is the basis of a preliminary classification: (1) no steady flow is observed where rainfall is less than $1000 \mathrm{~mm}$; and (2) steady flow is always present where rainfall exceeds $1600 \mathrm{~mm}$.

The intermediate range from 1000 to $1600 \mathrm{~mm}$ was subdivided into two subclasses: $1000-1250$ and $1250-1500 \mathrm{~mm}$ (no basin has a rainfall between 1500 and $1600 \mathrm{~mm}$ ).

In the first subclass $(1000-1250 \mathrm{~mm})$, flow differences depend mainly on parent.rock and weathering:

(1) All four sets of basins on sandstones (mainly in Mali, Cameroon and Brazil), show a low steady flow, always lower than $0.51 \mathrm{~s}^{-1} \mathrm{~km}^{-2}$, whether the area is covered with sands or ironstones.

(2) No representative basin on schists, mica schists or clays shows steady flow; this is the case for the seven sets of basins in Togo, Benin, the Ivory Coast and the Congo. Moreover, in the latter two countries, they are the only basins under climax forest with an equatorial climate.

(3) Four sets of basins without flow and three with some flow are observed on sands and granitic weathering materials. It is difficult to explain this difference, but it may be noted that whilst water tables are almost always present, their permanence is unconfirmed. These water tables are not sufficiently drained by these streams, except when there is a rock outcrop close to the outlet of the basin, which causes the water table to overflow. Nevertheless, the discharge is very low, less than $0.51 \mathrm{~s}^{-1} \mathrm{~km}^{-2}$, similar to that found on sandstones.

Therefore, given a mean annual rainfall of $1000-1250 \mathrm{~mm}$, a steady flow 
lower than $0.51 \mathrm{~s}^{-1} \mathrm{~km}^{-2}$ may be observed only on sandstones, sands and also on granites if the topographic conditions are favourable for the drainage of the water table.

In the 1250-1500 mm subclass, five sets of basins were observed to have steady flow whilst seven lacked steady flow. The first group comprises two sets on sandstones and three on granites; the second group comprises schistous basins and others on granites, gneiss and migmatites. As before, weathering materials and rocks clearly differentiate the two groups, although granites still raise some problems.

Temporary water tables with rapid depletion coefficient. 1/a ranging from 10 to 20 days were observed on very rough soils where gneiss and migmatites predominate and where annual rainfall is fairly well distributed $(6$ months $>0.1 P)$. On the other hand, permanent drained water tables are observed on calco-alkaline granites covered with a variety of weathering materials, either in the form of indurated laterite tableland or granitic sands. Rainfall - distributed over five months is another factor. In this case, dryseason discharge decreases with the area of the drained basin and can even fall to zero - this is shown by two sets of basins in northern Ivory Coast (Flakoho, Loserigué). Losses by infiltration in the channels, by evaporation and intakes in the densely populated intensively cropped zones are responsible for this. Typical mean monthly discharges are generally rather high, ranging from 1 to $71 \mathrm{~s}^{-1} \mathrm{~km}^{-2}$ in drained areas smaller than $100 \mathrm{~km}^{2}$, whatever the soil type. Discharge depletion is slow: $1 / a$ is often higher than 100 days.

Table 6. also shows the characteristics of dry-season flows in watersheds with high rainfall (over $1600 \mathrm{~mm}$ ). The values observed do not seem to be systematically higher than those of the 1250 to $1500 \mathrm{~mm}$ subclass, i.e. from 1 to $41 \mathrm{~s}^{-1} \mathrm{~km}^{-2}$ on granites as well as on quartzites and basalts not previously studied. However, one high value on sandstones must be noted, namely $91 \mathrm{~s}^{-1} \mathrm{~km}^{-2}$. Schistous soils covered with laterite cap and represented by a catchment set in Upper Guinea show a mean water table and low water similar to those observed on sandstones and granites where rainfall is less than $1200 \mathrm{~mm}$.

\section{CONCLUSION}

Extensive fieldwork, mainly conducted in intertropical Africa, has distinguished various flow processes, namely, runoff, subsurface runoff and runoff on saturated soil with groundwater rising to the surface; these types of flow are also present in colder regions. The conditions of rainfall, rock weathering, soil distribution and plant cover in three climate-defined environments lead to one or other type of flow, and their occurrence may be irregular throughout a well-marked rainy season. The conditions and intensity of occurrence of a particular type of flow may differ between the tropical and the colder zones. 
The main flow-generating processes are similar on plots of $1-50 \mathrm{~m}^{2}$ and on watersheds of several $\mathrm{km}^{2}$. The conditioning factors which account for these processes and the numerical indices considered are also affected by scale: But the scale increase from plot to watershed is less straightforward when quantifying the processes; more thorough experimental analysis of this is needed.

Sufficient observations have been made on the variable-source concept of the different types of flow in a watershed throughout the rainy season. Flow' modelling may be further improved only when this concept is an integral component: Therefore, the plot seems to be the basic element in modelbuilding." A model's structure must permit the division of the watershed into $n$ elements of hierarchical composition; based on the channel network (Girard et al., 1981). Rapid tests conducted using the sprinkling infiltrometer must permit termination of hydrological behaviour of plots selected from homogeneous soil-cover complexes (Beven and Kirkby, 1979; Casenave, 1982). These homogeneous complexes should be selected on the basis of surface morphostructures or complex three-dimensional internal structures, rather than by using genetic soil classifications.

$\therefore$ There are still some points which require further clarification: (1) the hydraulic pathway used by the subsurface runoff from the soil to the outlet of a watershed, (2) the precise impact of plant cover upon soil surface roughness and the significance of scale: Plot and watershed; and (3) the variability of the threshold value $F_{\mathbf{n}}$ of the infiltration capacity of a plot, as related to rainfall intensity and vegetation.

Finally, in order to improve comparison of watersheds, the identification of the variable "sources" of "flow types should lead hydrologists to use parameters such as the depth of surface runoff $R_{\mathrm{x}}$, or the surface runoff ratio $K_{x}$, relating these not only to the total area of the watersheds but also to that of the sources themselves. It would then be easier to transfer and use the data collected from plots, which could correspond to surface morphological complexes and easily be classified into a particular "source". of flow.

\section{ACKNOWLEDGEMENTS}

The author wishes to thank J.A. Rodier for reading this paper. His great experience has been extremely helpful in preparing the final version.

\section{REFERENCES}

Beven; K. and Kirkby, M., 1979: A physically based, variable contributing area model of basin hydrology. Bull. Int. Assoc. Sci. Hydrol., 24(1): 43-69.

Blancaneaux, $P_{.} \cdot 1973$. Notes de pédologie guyanaise. Les djougoungpété du bassin verssant expérimental de la crique Grégoire en Guyane Française. Cah. ORSTOM, Sér. Pédol., XI(1): 29-42. 
Boulet, R., Brugière, J.M. and Humbel, F.X., 1979. Relations entre organisation des sols et dynamique de l'eau en Guyane Française: conséquences agronomiques d'une évolution déterminée par un deséquilibre d'origine principalement tectonique. Sci. Sol, 1: 3-17.

Camus, H. and Berthault, C., 1972. Influence du couvert végétal sur la perméabilité des sols du bassin représentatif de Korhogo, Coste d'Ivoire. Cah. ORSTOM, Sér. Hydrol., IX(3): $3-14$.

Camus, H., Chaperon, P., Girard, G. and Molinier, M., 1976. Analyse et modélisation de l'écoulement superficiel d'un bassin tropical. Influence de la mise en culture - Côte d'Ivoire-Korhogo - 1962-1972. ORSTOM, Trav. Doc., No. 52, 81 pp:

Casenave, A., 1978. Etude hydrologique des bassins de Sanguéré. Cah. ORSTOM, Sér. Hydrol., XV(1-2): 3-209.

Casenave, A., 1982. Le mini-simulateur de pluie. Conditions d'utilisation et principes de l'interprétation des mesures. Cah. ORSTOM, Sér. Hydrol., XIX(4): 207-228.

Casenave, A., Guiguen, N. and Simon, J.M., 1982. Etudes des crues décennales des petits bassins versants forestiers en Afrique Tropical. Cah. ORSTOM, Sér. Hydrol., XIX(4): $229-252$.

Chevallier, P., 1982. Simulation de pluie sur deux bassins versants Sahéliens (Mare d'Oursi -Haute Volta). Cah. ORSTOM, Sér. Hydrol, XIX(4): 253-297.

Collinet, J. and Valentin, C., 1979 . Analyse des différents facteurs intervenant sur l'hydrodynamique superficielle. Nouvelles perspectives. Applications agronomiques, Cah. ORSTOM, Sér. Pédol., XVII(4): 283-328.

Dubreuil, P., 1960a. Etude hydrologique de petits bassins versants en Côte d'Ivoire. Rapport général, ORSTOM, Serv. Hydrol., $156 \mathrm{pp}$.

Dubreuil, P., 1960b. Etudes hydrologiques de petits bassins versants au Dahomey. Rapport général, ORSTOM, Serv. Hydrol.

Dubreuil, P., 1972. Recueil des Données de Base des Bassins Représentatifs et Expérimenteaux - 1951-1969. ORSTOM, Paris, 916 pp.

Dubreuil, P., 1974. Initiation à l'Analyse Hydrologique. Masson et ORSTOM, Paris, $216 \mathrm{pp}$.

Dunne, T., 1983. Relation of field studies and modeling in the prediction of storm runoff. J. Hydrol., 65: 25-48.

Girard, G., 1975a. Les modèles hydrologiques pour l'évaluation de la lame écoulée en zone sahélienne et leurs contraintes. Cah. ORSTOM, Sér. Hydrol., XII(3): 189-221.

Girard, G., 1975b. Application du modèle à discrétisation spatiale au bassin versant de l'Oued Ghorfa, Mauritanie. Cah. ORSTOM, Sér.Hydrol., XII(3): 167-188.

Girard, G., Ledoux, E. and Villeneuve, J.P., 1981. Le modèle couplé - Simulation conjointe des écoulements de surface et des écoulements souterrains sur un système hydrologique. Cah. ORSTOM, Sér. Hydrol., XVIII(4).

Hewlett, J.D. and Hebbert, A.R., 1967. Factors affecting the response of small watersheds to precipitation in humid areas. In: W.E. Sopper and H.W. Lull (Editors), Forest Hydrology. Pergamon, Oxford, pp. 275-290.

Lafforgue, A., 1977. Inventaire et examen des processus élémentaires de ruissellement et d'infiltration sur parcelles. Application d'une exploitation méthodique des données obtenues sous pluies simulées. Cah. ORSTOM, Sér Hydrol., XIV(4): 299-344.

Lafforgue, A., 1982. Etude hydrologique des bassins versants de Sakassou - Côte d'Ivoire -1972-1977. ORSTOM, Trav. Doc. No. 149, 342 pp.

Pilgrim, D., Cordery, I. and Baron, B., 1982. Effects of catchment size on runoff relationships. J. Hydrol., 58: 205-221.

Roche, M.A., 1979. Comportements hydrologiques comparés et érosion de l'écosystème forestier tropical humide à Ecerex en Guyane. ORSTOM, Cayenne, $56 \mathrm{pp}$.

Rodier, J., 1964. Régimes hydrologiques de l'Afrique noire, à l'ouest du Congo. ORSTOM, Paris, Mém. No. 6, 137 pp. 
Rodier, J., 1975. Evaluation of annual runoff in tropical African Sahel. ORSTOM, Trav: Doc., No. 145.

Rodier, J. and Auvray, C., 1965. Estimation of Discharges of Ten.Year Floods for Catch. ments with a Surface Area less than $200 \mathrm{~km}^{2}$ in West Africa. ORSTOM, Paris, $30 \mathrm{pp}$.

Roose, E.J., 1979: Dynamique actuelle d'un sol ferrallitique très désaturé sur sédiments 'argilo-sableux sous culture et sous forêt dense humide sub-équatorial du Sud de la' Côte d'Ivoire 1964-1976. Cah. ORSTOM, Sér. Pédol., XVII(4): 259-282; XVIII(1): $3-28$.

Sircoulon, J., 1964. Etude Hydrologique des Bassins Versants du Tiapalou et du Dodou. ORSTOM, Serv. Hydrol., Paris, 51 pp.

Tixier, J., 1953. Etude de crues sur un petit bassin de la région de Bangui. In: Annales Hydrologiques de la France Outre-mer. ORSTOM, Paris, pp. 29-47.

Valentin, C., 1981. Organisations pelliculaires superficielles de quelques sols de région subdésertique. Thèse Bème cycle, Univ. Paris VII, Paris.

Vuillaume, G., 1969. Analyse quantitative du rôle des facteurs du milieu physicoclimatique sur le ruissellement et l'érosion à l'issue de bassins de quelques hectares en zone sahélienne - Kountkouzout, Niger. Cah. ORSTOM, Sér. Hydrol., VI(4): 87-131. 